\title{
Boekbesprekings/Book Reviews
}

\begin{abstract}
C. De Jong: Skandinawiers in Die Tweede AngloBoere-Oorlog 1899-1902, Deel 1, Van Mafeking no Magersfontein en Paordeberg. Uitgegee onder beskermheerskap van Die NederlandsZuidafrikaanse Vereniging te Amsterdam. Amsterdam, 1983, pp 168. Met afbeeldings en kaarte. Prys R10,00 (verkrygbaar by die skruwer van Wouwstraat 82, Groenkloof, Pretoria 0001).
\end{abstract}

In hierdie publikasie word, as ' $n$ inleiding, allereers aandag aan die bevolkingsuffer van die Skandinawiese lande (Swede, Finland, Noorwee, Denemarke, Ysland) ten tue van die Tweede AngloBoere-oorlog en die omstandighede gewu wat die Skandinawiers in die tweede helfte van die 19de eeu gedwing het om hulle geboortelande te verlaat en hulle elders te vestig. Die trek na ons land was nooit groot nie. Dalk het ongeveer 1000 in Transvaal gewoon en onder meer tot vestiging aan die Witwatersrand en Pretoria oorgegaan.

Kort voor die vitbreek van die oorlog het die proBoere onder hulle onder leiding van ingenieur Christer Uggla, van die werkswinkel van die NZASM, die Skandinawiese korps en 'n veldambulans opgerig (23.9.1899). Op 4.10.1899 is die dienste van die vruwilligerkorps deur die Transvaalse Regering aanvaar. Johan Flygare, die seun can sendeling Carl L. Flygare, can Zoeloeland, wat 'n Transvaalse Burger was, is in die rang van veldkornet - as aanvoerder van 'n korps aangewys, wat ongeveer 100 lede getel het.

Op 24.10.1899 het die korps by Mafeking aangekom en doarna het ongeveer 50 van die lede, onder veldkornet flygare aan die slag van Magersfontein deelgeneem. Van hulle het, op die slagveld, 21 gesneumel terwul 20 gewond was en 'n paar lede gevange geneem is.

Die skruwer behandel daarna sekere, volgens hom verkeerde opvattings oor die optrede van die korps tydens die reeds genoemde slag ( $\rho$ 13-17).

Na die slag van Magersfontein is die vitgedunde korpsgeledere geheel of gedeeltelik gevul. Die Britse omsingeling te Paardeberg het, in Britse gevangeskap, die einde van die bestaan van die korps beteken, terwul die ambulans reeds vroeër in Britse hande geval het (16.2.1899).

Vir die oorlogvoerendes, wat die heldemoed van die Skandinawiers tudens die slag van Magersfon- tein bewonder het, was die optrede slegs van ondergeskikte belang binne die raamwerk van die slag. In hulle lande van herkoms het Skandinawiers die rol wat die korps by Magersfontein gespeel het, van meer betekenis beskou ( $p .21$ ).

In 1924 is herdenkingsbuyeenkomste in verband met die rol wat die Skandinowiers tudens die slag van Magersfontein gespeel in Stockholm, Oslo, Helsinki en Kopenhagen, sowel as in Kimberley, Johannes. burg en. Durban gehou. 'n Skandinawiese komitee het op Geloftedag 1927 twee monumente, albei in die vorm van 'n Waldemarkruis, onthul.

Later is die DTD onder meer aan Uggla toegeken, terwul hụ die herdenking van die slag van Magersfontein en die onthulling van die huidige oorlogsmonument (1969) die gesneuwelde Skandinowiers nie vergeet is nie ( $\rho$. 24). Die skilder Nils Anderson se histories belangrike skilderue bevind hulle in die Danie Theron krỵgskool, nabu Kimberley.

Die skruwer versterk daarna 'n aontal lewenssketse van lede van die korps en van hulle wat aan Britse kant geveg het, sowel as van die Noorse militêre attache aan Boerekont, Kapt Julius Allum (1865-1949).

'n Groot deel van die inhoud van die publikasie (pp. 56-177) word deur die vertaling van Matts Gustafsson en Nils Viklund se insiggewende publikasie Boerer och engelsman, Skildringer ur det sudafrikanska kriget 1899-1900 (Helsingfors 1910) in beslag geneem. Die werk is onder die titel Boere en Englese Beskrywings van die Suidafrikaanse oorlog 1899-1900 vir ons toeganklik gemack en, waar nodig, met anntekeninge toegelig.

Die vertaling van $\omega$. Boaerentzen se persoonlike envarings gedurende die oorlog, besloan met inbegrip van sy krugsgevangeskap, 30 bladsue (pp 122-152). Omtrent die lotgevalle van die. Skandinawiese ambulans het die Sweedse verpleegster Elin Lindblom haor herinneringe in 1924 op skrif geplaas ( $p \rho .157-164)$. Die herinneringe het in 1979 in die Krugshistoriese tudskrif (Johannesburg) verskụn.

In die tweede deel van die reeks beoog die skrywer om vertalings van die oorlogservarings van nog 'n aantal Skandinawiers, soos Kapt. Julius Allum en die Noorse vruwilliger Paul Schultz (wat aan Britse 
kant geveg het) aan su lesers voor lê. Die deel sal afgesluit word met A.C.H. Uggla se verslag oor die herdenkingsbyeenkomste van die slag van Magersfontein (Stockholm, 1926).

Op p. ix van die publikasie verskụn 'n bibliografie van bestaande werke in Afrikaans, Engels en Nederlands wat aandag aan die lotgevalle van die Skandinawiese korps wu, waaromtrent tans danksy die jongste publikasie - meer bekend en toeganklik gemaak is as in die verlede die geval was.

\section{Kol. Dr Jan Ploeger}

\section{Dick Wilson: Moo the peoples Emperor, Hutchin- son, 1979, R25.75}

Dick Wilson has written a detailed account of Mao Tse Tung's life, from his beginnings as a peasant's son, to the day he entered Peking to proclaim to China and to the world the beginning of a new order.

He invented for China a completely new sustem of life, economy and government. In the course of devising it he left behind a body of theoretical and expository writing - as well as a small collection of excellent poetry. His self-appointed task was the impossible one of dragging a decayed, corrupt and inefficient imperial order, which had moulded the Chinese people for many centuries, into modernity. By 1920, as a primary school headmaster, he became convinced that Communism was the only possible instrument for China to cut cleanly through to social justice and economic advance.

Mao struggled for thirty years to establish a Communist state with almost another thirty years of power to build Socialism in China.

His desire to seek power and to hold it, destroyed his own family: several of his children were lost in upheavals, his first wife met a violent death, his second wife died insane, while his third wife, two daughters and nephew were disgraced immediately after his own death, because of their political activities on his behalf.

The wonder of it is that Mao survived for so long. His position was often tenuous, and we will not know for several years what the Chinese themselves really think of Mao.

Mao's tragedy was that he could not in the end bring about all the reforms which he wanted for
China, he underestimated the resistance to them. This book presents the story of how he came to form those ideals, how he fought for them - against enemy and friend - and how in the end he failed.

\section{J.C. Boshoff}

\section{De Villiers, Dirk en Johanna: $P W$, Tafelberg 1984, pp. 375.}

Die verskunning van die eerste omvattende biografie oor die lewenswandel van die eerste staatspresident van Suid-Afrika onder die nuwe grondwetlike bedeling kon nie meer geleë gewees het nie. Terwul die Republiek van Suid-Afrika nou op die drumpel van 'n nuwe staatkundige bedeling staan en terselfdertyd sterk na vore tree as 'n dinamiese faktor in interstaotlike betrekkinge in Suider-Afrika, is dit begruplik dat dit allerweë ' $n$ nuwe belangstelling in die leidende staatsmanne gaande sal maak. $\in n$ die sentrale figuur in al dié gebeure is viteraard Pieter Willem Botha.

Soos tereg op die stofomslag aangedui word, het die skruwerspan Dirk en Johanna de Villiers wyd gesoek en diep gedelf in hul jarelange navorsing vir dié boek. Die eindresultaat is nie 'n enge en strakke kronologisering van biografiese feite nie, maar 'n gesaghebbende werk wat spreek van veelheid - nie net van feite nie, maar ook van insigte en perspektiewe.

Vanuit ' $n$ militêre oogpunt beskou, is dit veral die 5 de deel (DIE YSTERVUIS) wat in 1966 'n aanvang neem, wat van belang is. Nie alleen word die ampstermun van mnr P.W. Botha as Minister van Verdediging (en later Eerste Minister) in fokus gebring nie, maar dit word ook anngebied teen 'n wye agtergrondskildering van gebeure. Hierdie besondere kroniek het begin toe wulle dr Hendrik Verwoerd in April 1966 besluit het om mnr Botha as Minister van Verdediging aan te stel.

Mnr Botha se skertsende antwoord ("Maar Dokter, watter sonde het ek begaan dat jy my so moet straf?") was nogal nie sonder betekenis nie. Soos die skruwers trovens aandui, het mnr Botha "nouliks kon besef watter moeilike taak Verwoerd in 1966 aan hom opgedra het." Dit was die begin van ' $n$ nuwe en gevaarlike tudvak en Suid-Afrika, skaars losgesny van die Statebond, moes opnuut besin oor sy posisie in die internasionale gemeenskap. Dit was nie net die begin van koloniale ontvoogding in Suider-Afrika nie, maar ook van revolusionêre insluiping op die kontinent. En dan was daar die kwessie van wapenboikotte wat eers vruwillig- 